\title{
ON FRIENDS AND FALSE FRIENDSHIP IN THE POETRY OF GREGORY OF NAZIANZUS ${ }^{1}$
}

\author{
E R I K A B R O D Ň A N S K Á
}

\section{ABSTRACT}

Unlike family relations, friendships are based primarily on deliberate personal decisions. In some cases, however, they can be marked not only by sympathy and positive emotions but also by opportunism and conflicts. The relationship between two Church Fathers and close friends, St. Gregory of Nazianzus and St. Basil the Great, went through a whole range of emotions. A portrayal of this relationship, as well as several others (e.g. the one with Maximus the Cynic), is to be found in St. Gregory's autobiographical poem De vita sua. Some details on the saint's friends can also be perceived from his letters in verses, addressed to a group of more or less close friends from his surroundings. The variety and seriousness of the matters that St. Gregory discusses in these texts mirror the depth or superficiality of each particular relationship. In his letters in verses, Gregory of Nazianzus asks his friends for special favours (e.g. Hellenius), praises their deeds (e.g. some members of the monastic community in Caesarea), encourages them (e.g. Nemesius) or reprimands them (e.g. Vitalianus). A significant indicator of the level of friendship with the persons involved is the way St. Gregory addresses them. The salutations he uses are often very courteous, but in a couple of cases, marks of enmity can be found as well.

\section{Keywords:}

Gregory of Nazianzus; Poetry; Friends; St. Basil the Great; Cynic Maximus; Peraequator Hellenius

DOI: $10.14712 / 23363398.2020 .57$

$\mathrm{T}$ he life of St. Gregory of Nazianzus was constant strife between active life and desire for contemplative seclusion. This inner

\footnotetext{
1 This contribution was created as part of the implementation of the project VEGA 1/0114/17 Poemata moralia of Gregory of Nazianzus.
} 
struggle is conspicuous in many of Gregory's writings, foremost in the poetry written by the end of his life, reflecting author's experiences, opinions and convictions. The perception of Christian values and their significance for the world inspired the poems with moral undertone, ${ }^{2}$ in which he is comparing the worldly and the spiritual life. Gregory reflects upon human virtues, moral integrity, restraint, patience, but also human nature in general. He denounces excessive wealth, envy, laziness, or the beauty of women, encourages people to turn away from idols and focus on God. He does not evade issues such as anger, lust for property or false friends. ${ }^{3}$

Two short poems bear upon the theme of fake friendship. They are written in iambic trimeter ${ }^{4}$ that lets the poet easily adapt various moods.

\begin{tabular}{|c|c|}
\hline 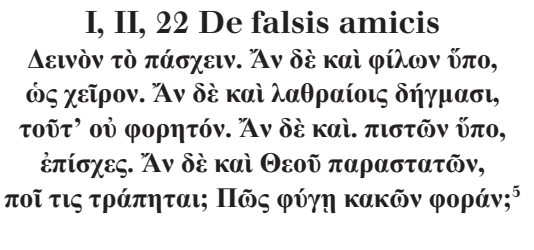 & 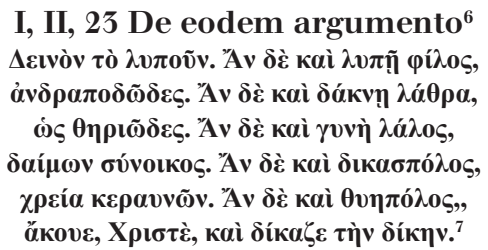 \\
\hline
\end{tabular}

2 The criteria for organizing Gregory's poetic work, as proposed by Patrologia Graeca (Patrologiae cursus completus, accurante J.P. Migne, series graeca (PG) 35-38), are the theme of individual poems and the intended audience, even though we have little information on the latter. The poetry of Gregory of Nazianzus is in the 37th volume of $P G$ and is divided into two books (poemata theologica, poemata historica). Both books are further subdivided into two parts: I, I Poemata dogmatica; I, II Poemata moralia; II, I Poemata de se ipso; II, II Poemata quae spectant ad alios.

3 Erika Brodňanská, Gregor z Nazianzu: Listy vo veršoch (Prešov: Prešovská univerzita, 2012), 37.

4 Greeks considered iambic meter to be appropriate for the narrative literature because of its resemblance with spoken language (Bernard von Wyss, 'Gregor von Nazianz. Ein griechisch-christlicher Dichter des 4. Jahrhunderts,' Museum Helveticum 6, (1949): 192). As for the use of iambic meter, Gregory drew inspiration from Euripides' and Sophocles' tragedies, but also from the more recent works of Menandros, whose influence is evident especially in moralizing passages.

5 It is hard to suffer, but it is ever harder if it is by the hand of a friend. It is intolerable when they bite you unexpectedly. What if it is those who are faithful? Endure it. And what if you suffer from the hands of those who are close to God? Where to seek assistance and how to escape the evil?

${ }_{6} \quad$ There has been incertitude concerning the origin of the poem. While Robert Keydell ('Die Unechtheit der Gregor von Nazianz zugeschriebenen Exhortatio ad virgines,' Byzantinische Zeitschrift 43, no. 2 (1950): 334, note 1) asserts Gregory to be the author, H. Werhahn ('Dubia und Spuria unter den Gedichten Gregors von Nazianz,' Studia patristica VII (1966): 342) expresses doubts concerning the poem's authenticity.

7 Disgrace is a big burden. If a friend humiliates you, it is vile. If he debases you behind your back it is beastly. If your reputation is sullied by a gossiping woman you are 
The poems share the theme and the meter, but broader similarities concern specific ideas expressed in the verses as well as the word choice. Gregory thus emphasizes the importance of the message: the words ' $A v \delta \dot{\varepsilon} \kappa \alpha \grave{l}$ are repeated in the middle of the verses and the poems are concluded by the mention of the people ranking highest on the imaginary credibility scale.

The poem I, II, 22 warrants the impression that Gregory could write it under the influence of disillusionment with St. Basil the Great's friendship. The author briefly and clearly reiterates what he detailed in the autobiographical poem De vita sua (II, I, 11). ${ }^{8}$

Gregory and Basil had already met during their studies in Cappadocia, but their friendly relationship - as we learn from Gregory's verses had deepened later, at the Plato's Academy in Athens: ${ }^{9}$

Basil, of course, it was, the great ornament of our generation. In studies, in lodgings, in discussions I had him as companion. We made a team, if I may boast a little, that was celebrated throughout Greece. We had all things in common, and a single soul, as it were, bound together our two distinct bodies. But above all it was God, of course, and a mutual desire for higher things, that drew us to each other. As a result we reached such a pitch of confidence that we revealed the depths of our hearts, becoming ever more united in our yearning ${ }^{10}$ (II, I, 11, 226-235; PG 37, 1045).

The relation between the two friends continued after their return home from studies. While Gregory had been torn between a constant urge of social responsibility that pushed him to engage in public life and the desire to retreat, Basil was visiting the centres of monasticism in Palestine, Egypt, Syria, and Mesopotamia. Basil later settled in Annisoi in Pontus, where he tried to live a life of an eremite. Under the influence of his friend, Gregory tried to practice ascetism, but he was

facing a demon. Yet if the humiliation comes from a judge it is like being struck by a thunder. If the perpetrator is the servant of God, Jesus, listen and judge.

8 Gregory's friendship with Basil the Great, its intensity, development and unexpected turns resonate in other Gregory's works, be it poetry, lyrics, or letters.

9 Gregory of Nazianzus spent about seven years in Athens (350-356/358). His teachers were rhetoricians Himerius and Prohairesius, and classmate, apart from Basil the Great even the future Emperor Julian, also known as Julian the Apostate. (Kristoffel Demoen, Pagan and Biblical Exempla in Gregory Nazianzen (Brepols, 1996), 19).

10 English translation cited from: Denis Molaise Meehan, Saint Gregory of Nazianzus: Three Poems (Washington, D. C.: The Catholic University of America Press, 1987), 83-84. 
not convinced that it was his vocation. Nonetheless, Gregory dealt with his life crises by escaping to Basil in Pontus (II, I, 11, 351-356; PG 37, 1053-1054):

Like an ox stricken by the gadfly I made for Pontus, anxious to have the most godly of my friends as medicine for my agitation. For there, hidden in that cloud, like one of the sages of old, practising union with God, was Basil, who is now with the angels. With him I soothed my agony of spirit. ${ }^{11}$

The reversal in the long-term friendship happened in 370, when Basil became the Bishop of Caesarea Bishop and Metropolitan of the entire Cappadocia. Gregory felt that the sense of necessity of the friendship had been lost, and that Basil betrayed his commitment to being devoted to philosophical life, ${ }^{12}$ that is to say to apply religious theory into everyday life and practice. ${ }^{13}$ The relationship worsened when Basil ordained Gregory Bishop of Sasima (nowadays Silifka), situated in a relatively inhospitable region. Gregory accepted the ordination, but did not approve of Basil's decision (II, I, 11, 389-394; PG 37, 1056):

Basil, the closest of our friends, came to visit us. (I should like to pass over intervening events in silence, lest I seem to speak in insulting terms about a man whose eulogy I've just pronounced.) He came, alas for the story, but I must tell it all the same. He was to prove another father to me, and a far more burdensome one. My real father, even though he tyrannized over me, I must shelter; but no such duty holds in his case, where friendship actually brought injury instead of deliverance from trouble. ${ }^{14}$

While Gregory's views on friendship were sentimental and emotional, Basil's approach was more formal, since he viewed it as a means of reaching goals. ${ }^{15}$ Moreover, Gregory perceived friendship with Basil through the prism of his respect for the classical culture and the love of Athens that brought them together. However, for Basil, the time spent

\footnotetext{
English translation cited from: Meehan, Saint Gregory of Nazianzus, 87.

Cf. Caroline White, Gregory of Nazianzus: Autobiographical poems (Cambridge: University Press, 1996), XV.

13 Cf. Helena Panczová, Sv. Makrína, Melánia a Olympia (Trnava: Dobrá kniha, 2008), 11.

14 English translation cited from: Meehan, Saint Gregory of Nazianzus, 88.

15 Raymond Van Dam, Families and Friends in Late Roman Cappadocia (Philadelphia: Pennsylvania University Press, 2003), 165.
} 
studying in Athens did not mean much. He perceived it to be rather vain and worthless. ${ }^{16}$ Despite personal differences and later aversion, Gregory never ceased hoping for the restoration of the old friendship. ${ }^{17}$

However, let's return to Gregory's poem I, II, 22. We can clearly see the parallels between Gregor Nazianzus' relationship with Basil and its portrayal in his autobiographical poem. Gregory was reluctant to

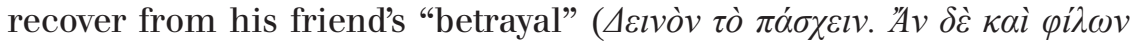

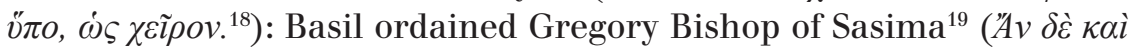
$\lambda \alpha \theta \rho \alpha i o r \varsigma \delta \eta_{\gamma} \mu \alpha \sigma l, \tau o \tilde{v} \tau^{\prime}$ ov $\left.\varphi \circ \rho \eta \tau o ́ v .{ }^{20}\right)$. The blow was all the more difficult to bear that Basil was his confidant and close friend ${ }^{21}$ ("Av $\delta \dot{\varepsilon} \kappa \alpha i$. $\pi l \sigma \tau \tilde{\omega} v$

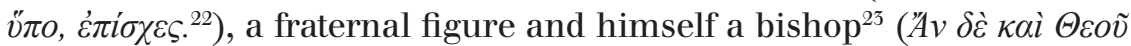
$\pi \alpha \rho \alpha \sigma \tau \alpha \tau \tilde{\omega} v, \pi \circ \tilde{\imath} \tau l \varsigma \tau \rho \alpha ́ \pi \eta \tau \alpha l ;$; $\tilde{\omega} \varsigma \varphi v ́ \gamma \eta \eta$ falsis amicis and II, I, 11 De vita sua use the same meter - iambic trimeter - and therefore they could be considered as versified speech, easily accessible to both, readers and listeners.

St. Basil the Great was not the only friend who disappointed Gregory of Nazianzus. In the poem De vita sua, he also refers to Cynic ${ }^{25}$ Maximus who, after conversion to Christianity, came to Constantinople from Egypt at the end of the year 379 or the beginning of the year 380. Gregory welcomed him wholeheartedly and provided hospitality for him. In one of the speeches (Or. 25), Gregory even praised Maximus as an excellent Christian philosopher and a hero in the struggle for Nicene Creed. ${ }^{26}$ Gregory did not know that Maximus' friendship was not honest

16 Van Dam, Families and Friends, 171-172.

17 Van Dam, Families and Friends, 184.

18 It is hard to suffer, but it is ever harder if it is by the hand of a friend. (I, II, 22, 1-2a; PG 37, 789).

19 Carm. II, I, 11, 389-394 (PG 37, 1056).

20 It can hardly be borne when they unexpectedly die. (I, II, 22, 2b-3a; PG 37, 789).

21 Carm. II, I, 11, 226-235 (PG 37, 1045).

22 What if it is those who are faithful? Endure it. (I, II, 22, 3b-4a; PG 37, 789).

23 Carm. II, I, 11, 351-356 (PG 37, 1053-1054).

24 And what if you suffer from the hands of those who are close to God? Where to seek assistance and how to escape the evil? (I, II, 22, 4b-5; PG 37, 789).

25 Cynicism was a school of thought in ancient Greek philosophy. For the Cynics, living a happy and virtuous life means despising social norms, rejecting wealth, glory, all sensuous enjoyment, achievement of independence and inner freedom. Cynicism was an exclusively ethical movement with no aspiration to resolve the greater truth of existence, nor a developed systematic teaching or theoretical framework to study empiric reality. (Lívia Flachbartová, Diogenovský kynizmus ako spôsob života (Prešov: Filozofická fakulta Prešovskej univerzity, 2015), 11).

26 John A. McGuckin, St. Gregory of Nazianzus. An Intellectual Biography (New York: St. Vladimir's Seminary Press, 2001), 311; Carm. II, I, 11, 978 (PG 37, 1096). 
and that he only wanted his own benefit: Maximus was to be secretly ordained by the Alexandrian priests as the bishop of Constantinople although at that time the position was held by Gregory himself. After being disillusioned by Maximus, Gregory describes him as follows (II, I, 11, 750-756; PG 37, 1081):

At that time the city harbored an Egyptian freak. He was of dubious sex, a raging pest, a dog, a cynic, a street-lounger, an Ares, an inarticulate nuisance, a colossal monster. Fair? dark? curly? straight-haired? He had been one way, then recently he had contrived ${ }^{27}$ to be the other - the coiffeur's art could do him all over again. ${ }^{28}$

In the other verses, Gregory confesses being ashamed ${ }^{29}$ of being fooled by Maximus as well as for praising him the shame that he has left him, and it has been praised by him (II, I, 11, 952b-967; PG 37, 1094-1095):

Personally, though I've been wronged by him, his previous record convulses me with shame. "O come now, was he not, only yesterday, a friend of yours? Didn't you consider him worthy of the greatest praise?” It's easy to run across people who know the details, and find fault with my naiveté at the time, in showing respect to the most inferior of Cynics. Indeed the ignorance I displayed deserves censure. Like Adam I was undone by the nasty taste. To look at, the fruit that was really bitter seemed ripe. A style of conversation and protestations of loyalty that were skin deep only led me astray. For a trusting person is the easiest in the world to persuade since he is impulsively drawn to goodness, real or counterfeit. We are very conveniently constituted. To be sure each of us thinks what he wants to think. ${ }^{30}$

A comprehensive description of all the events surrounding Maximus was presented by Gregor in the poem within the span of about 360 verses. ${ }^{31}$ In the end, Gregory asks his readers for forgiveness for

27 Maximus took meticulous care of his hair and changed his hairstyle in the course of events.

28 English translation cited from: Meehan, Saint Gregory of Nazianzus, 98.

29 For more information on emotions in the poetry of Gregory z Nazianzus, see Christos Simelidis, 'Emotions in the Poetry of Gregory of Nazianzus,' Studia Patristica LXXXIII, (2017), 91-101.

30 English translation cited from Meehan, Saint Gregory of Nazianzus, 103-104.

31 Carm. II, I, 11, 750-1112 (PG 37, 1081-1105). 
his naiveté and for making similar mistakes because of his generosity when estimating other people. ${ }^{32}$

However, there are not only pointed statements against enemies and false friends in Gregory's poetry. To the contrary, verses taken from various poems indicate the preciousness of friendship. As examples of more general statements, one gnomic ${ }^{33}$ poem (I, II, 3354) could be mentioned, dealing with different ethical questions while teaching how to live a proper life ${ }^{35}$ :

Nothing is worthy of a devoted friend,

Tested by the storms of time,

He would give you only what is useful.

Know the limits of enmity, but not the boundaries of friendship. (I, II, 33, 177-180; PG 37, 941)

Aristotle in the 8th and 9th books of the Nicomachean Ethics deals with friendship in a similar way. He states a few proverbs pertaining to friendship (one soul; friends share everything, friendship is equality; etc. $)^{36}$ and characterizes friendship as something essential and beautiful. Aristotle considers as good friends those who wish the best for the friends themselves. ${ }^{37}$ Similar statements are found in Cicero: Amicitia est voluntas bona erga aliquem causa illius. ${ }^{38}$ The same words are present, in a modified form, in the works of St. Augustine (De div. quaest. LXXXIII, 31, 3).

Reading Gregory of Nazianzus' gnomic poetry, one can ask whether he was only a theoretician and a 'moralist', or whether he had been able to apply the recommendations from the verses in his own life. To some extent, the answer can be found in his autobiographical poem $D e$ vita sua, but also in the poems, poetic letters addressed to the people who surrounded him (poemata quae spectant ad alios). In them, he

\footnotetext{
McGuckin, St. Gregory of Nazianzus, 319.

Gnomic poetry is when a saying is put into verse, expressing an ethical guidance.

Carm. I, II, 33 (PG 37, 927-945) Tetrastichae sententiae (Sayings in quatrains).

35 Gregory of Nazianzus took up gnomic poetry as the first of the Christian authors. He had probably been inspired by lesser-known authors such as Naumachios and Fokylides. Only fragments of their works have been preserved. (Hendrik Leonardus Davids,: De Gnomologieën van sint Gregorius van Nazianze (Nijmegen - Utrecht: Dekker \& Van de Vegt N.V., 1940), 13).

36 Aristotle, Eth. Nic. 9, 8.

37 Aristotle, Eth. Nic. 8, 4.

38 Cicero, De inv. II, 55, 166.
} 
revealed a deep relationship to his mother, a complicated relationship to his father, a close relationship with his siblings, but presented as well a variety of relationships with his friends, showing, among other things, his generosity. Through the letters in verses he asks friends for kindness (e.g. Hellenius and Julian, II, II, 1; 2), he praises the deeds (e.g. selected personalities of the Caesarean community, II, II, 1), he encourages them (Nemesius II, II, 7), but also reprimands (e.g., Vitalian II, II, 3).

Particularly interesting of these poems on friendship is the one addressed to Hellenius (II, II, 1). It is, to a certain extent, a source of information on Gregory's relationship to Hellenius, and, at the same time, it reveals the author's links to members of the monastic community in Diocaesarea in Cappadocia.

The addressee, Hellenius, belonged to a circle of friends formed by Gregory and Basil the Great during their studies in Athens. ${ }^{39}$ Hellenius came from a rich family from Armenia, he was a Christian, and in Athens, he studied rhetorics. Basil knew him from Pontus because he was one of the pupils of Basil's father. Basil described Hellenius in two of his letters (Epp. 71; 98) as 'the venerable brother Hellenius'. ${ }^{40}$ When Hellenios became a peraequator ${ }^{41}$ in Nazianzus, he also received a letter in verses from Gregory himself (Ad Hellenium pro monachis exhortatorium) asking for relief from taxes for local monks ${ }^{42}$ (II, II, 1, 281-286; PG 37, 1471):

Show your compassion, my friend. It will bring little benefit to me, but you will gain a lot. It will bring you an enduring gift you can share and treasure with your wife and children, for it is the promise of a better life.

If you happened to recall how friendly we used to treat each other, you would know that of all the friends I had, you were my dearest. ${ }^{43}$

When we want to speak of Gregory's letters on friends and addressed to friends, we have to recognize that the current meaning of the words

\footnotetext{
Van Dam, Families and Friends, 139-140.

40 Daniel Škoviera (transl.), Sv. Batil Velký: Povzbudenie mladým. Listy I. (R. 357-374) (Trnava: Fakulta humanistiky Trnavskej university v Trnave, 1999), 146 and 178.

41 Peraequator's office appeared in the Roman Empire for the first time under the rule of Emperor Constantine and was established to guarantee honesty in the census. Peraequator's role was to listen to objections against the estimates of tax liability.

42 Cf. Van Dam, Families and Friends, 145.

43 Erika Brodňanská, Gregor z Nazianzu: Listy vo veršoch, 115.
} 
friend and friendship does not completely overlap with their meaning in Antiquity. On the one hand, they indicated the close relationship between two or more people, but on the other, they were often used in a pure formal setting. In the correspondence, e.g. in a business exchange, the word friend often referred to a person to whom the writer did not feel any particular personal sympathy. ${ }^{44}$ Hence, other means of indicating the nature of the relationship were put in place, especially adjectives referring to the addressee, ${ }^{45}$ which is also the case of the poetic letter to Hellenius.

In literature, we encounter different forms of address in the works of Homer, especially in his Iliad, and in the drama, where it originates in the richness of dialogues. It is important to note, that in contrast to epics, the addresses in drama often display shifts in meaning. The poetic letters of classically educated Gregory of Nazianzus are influenced by both ${ }^{46}$ traditions, and the letter to Hellenius is not an exception. Addresses appear in the prologue of the letter in which Gregory used the adjectival form ö $\rho \imath \tau \tau \varepsilon^{47}$ (the best), and in the epilogue and verses 281-356, in which Hellenius asked for tax relief for monks. Within the span of 11 verses, Gregory addresses Hellenius three times: $\varphi \varepsilon ́ \rho \imath \sigma \tau \varepsilon^{48}$ (beloved), $\dot{\alpha} \gamma \alpha \nu \omega ́ \tau \alpha \tau \varepsilon \dot{\varepsilon} \tau \dot{\alpha} \rho \omega v^{49}$ (most precious of friends) a $\tilde{\omega} \mu \alpha \dot{\alpha} \kappa \alpha \rho^{50}$ (blessed). In the epilogue, two adjectives and one

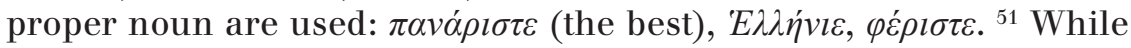
Gregory used the traditional $\not \partial \rho \sigma \tau \varepsilon$ known since Homeric times, ${ }^{52}$ the form $\pi \alpha v \alpha \dot{\rho} \rho \sigma \tau \varepsilon$ could be found in Lukianos' satire Fugitivi (2nd century CE) and later authors. ${ }^{53}$ The adjective $\mu \alpha \dot{\alpha} \kappa \alpha \rho$ signified respectful

${ }^{44}$ Heikki Koskenniemi, Studien zur Idee und Phraseologie des griechischen Briefes bis 400 n. Chr. (Helsinki: Akateeminen Kirjakauppa, 1956), 115-116.

45 Our knowledge of the ways of addressing people and expressions of politeness in letters of the 4th century CE consists mainly in knowing the letters of that period, whether pagan (e.g. from the rhetorician Libanius or Emperor Julian) or from the letters of the Church Fathers. The choice of means of addressing depends on the traditional, Classical usage. (Henrik Ziliacus, Untersuchungen zu den abstrakten Anredeformen und Hôflichkeitstiteln im Griechischen (Helsinfors, 1949) 30-35, 58-60).

46 Erika Brodňanská, 'Formy oslovenia v básnických listoch Gregora z Nazianzu,' in Úvod do štúdia gréckej filológie, ed. Ján Zozul'ak (Prešov: Datapress, 2011), 17-18.

${ }_{47}$ Carm. II, II, 1, 17 (PG 37, 1453).

48 Carm. II, II, 1, 281 (PG 37, 1471).

49 Carm. II, II, 1, 285 (PG 37, 1472).

Carm. II, II, 1, 292 (PG 37, 1472).

Carm. II, II, 1, 357; 359; 365 (PG 37, 1476-1477).

Homeros, Il. III, 39; XIII, 769; XVII, 142; XXIII, 483.

53 Brodňanská, 'Formy oslovenia,' 20. 
tone in the tragedies, and $\varphi \varepsilon ́ \rho ı \sigma \tau \varepsilon$ indicated duty rather than devotion since Homer's ${ }^{54}$ epics. ${ }^{55}$

What is the meaning of all these words in Gregory's poetic letter? They reveal a relationship based on mutual respect and common past more than of a deep friendship. This inference is supported by the fact that whereas not a single of Gregory's letters written in prose was dedicated to Hellenius, several letters (as well as epitaphs) were addressed to the men mentioned in the poem. Gregory took advantage of his old acquaintance from student days, to lobby for the men who were obviously much closer to him.

The assumption that the relationship between Gregory and Hellenius was not too close is supported by the prologue of Gregory's poem. The reason Gregory wrote the poem was not only his effort to lower the monetary burden of monks, but probably also Hellenius' request to Gregory where he asks him to write a major work, although Hellenius himself did not intend to do so (II, II, 1, 1-10; PG 37, 1451-1452):

Do you want to hear how eloquent am I? There is no eloquence left in me. For I have abandoned the art of rhetoricians.

Instead I laid on my shoulders the pleasant burden of the cross, which is my salvation.

Christ, our Lord, has replaced all that was made by the hand of men.

Expressing sweet words of praise is no longer my ambition

For in the precious Word of God there is no liking in it.

I will never praise neither your kin nor your wealth that leave others in awe, I will never glorify your eloquent voice stronger than a thunder,

I will never retell the fabulous tales about you and your brother that you cherish,

Because you are both, skillfully wielding power over cities.

Gregory apparently made a conscious choice of meter, since he wrote the poem using elegiac couplet that has been known to be the used for elegies, grave inscriptions, aphorisms, epigrams as well as parainetic poems advising on bravery, defense of the homeland, or the proper management and enjoyment of one's life. Therefore, the poem to Hellenius is primarily an encouraging letter in verses, but at the

${ }^{54}$ Homeros, Il. VI, 123; XV, 247; XXIV, 387; Od. I, 405; IX, 269.

55 Ziliacus, Untersuchungen, 14-15, 20. 
same time it expresses a certain amount of trust in Hellenius as well as Gregory's affection for the members of the monastic community who have been entrusted to him.

Although the men were mostly wealthy and successful, they gradually changed their lifestyle, renounced their possessions and started a life of abjection. It is not entirely clear how and when they created a community in Diocaesarea, but from the names listed in the poem one can assume that they followed Gregory as their teacher, or they belonged to the circle of his closest people, although not all of them had direct ties to the church in Nazianzus and not all were ordained priests. ${ }^{56}$ Gregory presents the men belonging to the community to Hellenius by name, offering more or less detailed information on all of them. He talks about the loving Cledonius the Presbyter ${ }^{57}$ who provided for the needy and who consecrated his life to Christ. Gregory then speaks of the brothers Eulalius ${ }^{58}$ and Helladius, ${ }^{59}$ to whom he refers to in one of his prosaic letters $(15,4)$ as his noble cousins. Gregory does not forget to mention Karterius ${ }^{60}$ one of his first teachers in Nazianzus, who also accompanied him during his studies abroad and later became a clergyman or monk. He dedicates almost 30 verses to Nicomedes, who was his relative. Gregory praises Nicomedes for nurturing his children and bringing them to God, as well as for devoting himself to life in poverty because Nicomedes donated all his possessions to the

56 Cf. Neil McLynn, 'Among the Hellenists: Gregory and the sofists,' in Gregory of Nazianzus: Images and Reflections, eds. Bøtnes, J. - Hägg, T. (Copenhagen: Museum Tusculanum Press, 2006), 230-231.

57 He held a high office that he gave up to become a priest. Some authors associate him with Cledonius the Presbyter, to whom Gregory addressed the letters 101 and 102 concerning the 'fight' against apollinarists. (Cf. Marie-Madelaine Hauser-Meury, Prosopographie zu den Schriften Gregors von Nazianz (Bonn, 1960), 55; A. H. M. Jones, J. R. Martindale and J. Morrris, The Prosopography of the Later Roman Empire, Volume 1, A.D. 260-395 (Cambridge - London - New York - Melbourne, 1975), 213).

58 Eulalius lost his brother before the year 372 and in the same year he was already listed as one of the monks of Nazianzus. At that time, he tended for his mother. Since 373, he has served under Gregory as a bishop and eventually became Gregory's successor in Nazianzus. Gregory addressed him three letters $(116,117,158)$ (Cf. Hauser-Meury, Prosopographie, 70; Michael Wittig, Gregor von Nazianz. Briefe (Stuttgart: Hiersemenn, 1981), 152, 175, 249).

59 Helladius led a monastic way of life with his brother Eulalius. He died young, shortly before Gregory wrote a poem to Hellenius (Cf. Hauser-Meury, Prosopographie, 96). In memory of Helladius, Gregory wrote 3 epitaphs (37-39).

60 In memory of Karterius, Gregory wrote 4 epitaphs (115-118). Karterius probably did not belong to the community around Gregory of Nazianzus (cf. verse 139). He died after 374 CE. (Cf. Hauser-Meury, Prosopographie, 52). 
building of a church. ${ }^{61}$ In addition to these, Gregory presents the silent and loving Theognis, the pure-hearted Euandrus, the reasonable Asterius, his pupils of Philadelphius and Makrobius, the noble Rhegius, the wise Leontius and Heliodorus. Each of them excels in something else, but as Gregory states, together they are the building blocks of a great temple (II, II, 1, 119-224, PG 37, 1460-1467). When describing their qualities, Gregory widely uses metaphors. He emphasizes thus the importance of these men, his relationship to them, as well as the importance and the urgency of their demand to reduce taxes. The men

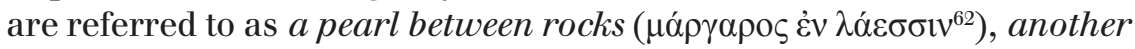

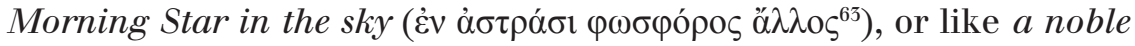

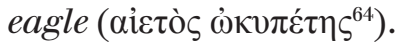

When talking about the men, it is interesting to note, that Gregory, in an attempt to influence Hellenius' decision, compares the deeds of two of his friends, Nicomedes and Theognis, to the most prominent figures of the Old Testament, to Abraham $^{65}$ (Gen 22,1-13) and James ${ }^{66}$ (Gen 28,12-15). Just as Abraham did not hesitate to sacrifice to God his son Isaac, neither Nicomedes hesitated to offer the best of him in sacrificing his own children. Although he was not asked to kill the children, their consecration had a similar effect - Nicomedes gave up the opportunity to see the continuation of his lineage. When referring to Theogonis, Gregory emphasizes his kindness and rapid advances concerning virtues. An explicit expression of this fact can be found in the poem in which Gregory references the dream of Isaac's son James from the Old Testament Book of Genesis, in which he saw a ladder connecting heaven and earth, with ascending and descending angels. A ladder symbolizes communication between heaven and earth and, simultaneously, God's closeness. The steps of the ladder represent virtues that can bring people to heaven. ${ }^{67}$

Although Gregory does not explicitly point out the nature of the relationship to the men of the monastic community, and he does not refer

61 See Hauser-Meury, Prosopographie, 133. In memory of Nicomedes Gregory wrote 3 epitaphs (112-114).

62 Carm. II, II, 1, 125 (PG 37, 1460).

63 Carm. II, II, 1, 125 (PG 37, 1460).

${ }^{64}$ Carm. II, II, 1, 160 (PG 37, 1463).

65 Carm. II, II, 1, 143-147 (PG 37, 1462).

${ }_{66}$ Carm. II, II, 1, 171-188 (PG 37, 1464-1465).

${ }_{67}$ Peter Dubovský (ed.), Genezis. Komentár k Starému zákonu (Trnava: Dobrá kniha, 2008), 556-557. 
to any of them by the word friend, the poetic devices used to describe them are eloquent enough. The tone Gregory uses when portraying men belonging to the community (the wider community of friends) and the way he is addressing Hellenius, are diametrically different. In the space of a single poem he reveals a whole range of possible shades of friendship, based on a common goal of seeking God and wisdom, as well as in applying religious theory in practice. After all, Aristotle has already expressed the opinion that friendship is based on the community and sharing of its members. ${ }^{68}$

In the poetry of Gregory of Nazianzus, there are many other instances of referring to his relationship to other people. His stance is straightforward. Gregory's personal poetry reveals his feelings; he openly admits his sympathy and affection to loved ones, and at the same time he is not avoiding writing about emotions like anger, shame, disillusionment or disappointment. The personal pain and experience of being betrayed by a friend (especially by Basil the Great) is so hurtful that at the end of the poem I, II, 22 De malis amicis as well as in the autobiographical poem II, I, 11 De vita sua Gregory opens up and shares his innermost pain and injuries with the recipient. It is clear though that Gregory himself knows how to address this pain - by turning to God, while speaking out about it and warning that a friend can be false and malevolent. Though, Gregory can revert into an impersonal mode. When addressing the general audience (e.g. poemata quae spectant ad alios), he treats the themes and ideas that resonated in the works of ancient authors and are perceived as loci communes. Nevertheless, even in such cases, he takes a clear stance, points out the ethical values and the importance of friendship, all the while condemning enemies or fake friends. Of all, he ascribes the highest importance to the friendship that is straightforward and without any side thoughts. For Gregory, living the life of a philosopher meant to be utterly, in actions and thought, devoted to the Christian way of life.

Faculty of Arts, University of Presov Institute of Roman Studies

Ul. 17. novembra 1 08001 Prešov Slovakia E-mail: erika.brodnanska@unipo.sk

${ }^{68}$ Aristotle, Eth. Nic. 8, 11. 